\section{(6) OPEN ACCESS}

\title{
Clinical spectrum and pleiotropic nature of $C D H 1$ germline mutations
}

\author{
Joana Figueiredo, 1,2 Soraia Melo, 1,2,3 Patrícia Carneiro, ${ }^{1,2}$ Ana Margarida Moreira, 1,3,2 \\ Maria Sofia Fernandes, ${ }^{1,2,4}$ Ana Sofia Ribeiro, ${ }^{1,2}$ Parry Guilford, ${ }^{5}$ Joana Paredes, ${ }^{1,3,2}$ \\ Raquel Seruca ${ }^{1,3,2}$
}

${ }^{1}$ Epithelial Interactions in Cancer Department, Instituto de Investigação e Inovação em Saúde (i3S), Porto, Portugal ${ }^{2}$ Epithelial Interactions in Cancer, Institute of Molecular Pathology and Immunology of the University of Porto (IPATIMUP), Porto, Portugal ${ }^{3}$ Medical Faculty of the University of Porto, Porto, Portugal

${ }^{4}$ Institute for Systems and Robotics (ISR/IST), LARSyS, Bioengineering Department, Instituto Superior Técnico, Universidade de Lisboa, Lisbon, Portugal

${ }^{5}$ Cancer Genetics Laboratory, Centre for Translational Cancer Research (Te Aho Matatū), Department of Biochemistry, University of Otago, Dunedin, New Zealand

\section{Correspondence to}

Dr Joana Figueiredo, Instituto de Investigação e Inovação em Saúde (i3S), Porto 4200-135, Portugal;

jfigueiredo@ipatimup.pt

Received 16 October 2018 Revised 5 December 2018 Accepted 10 December 2018 Published Online First 19 January 2019

Check for updates

(C) Author(s) (or their employer(s)) 2019. Re-use permitted under CC BY-NC. No commercial re-use. See rights and permissions. Published by BMJ.

To cite: Figueiredo J, Melo $S$, Carneiro P, et al. J Med Genet 2019:56:199-208.

\section{ABSTRACT}

CDH1 encodes E-cadherin, a key protein in adherens junctions. Given that E-cadherin is involved in major cellular processes such as embryogenesis and maintenance of tissue architecture, it is no surprise that deleterious effects arise from its loss of function. $\mathrm{E}$-cadherin is recognised as a tumour suppressor gene, and it is well established that $\mathrm{CDH} 1$ genetic alterations cause diffuse gastric cancer and lobular breast cancerthe foremost manifestations of the hereditary diffuse gastric cancer syndrome. However, in the last decade, evidence has emerged demonstrating that $\mathrm{CDH} 1$ mutations can be associated with lobular breast cancer and/or several congenital abnormalities, without any personal or family history of diffuse gastric cancer. To date, no genotype-phenotype correlations have been observed. Remarkably, there are reports of mutations affecting the same nucleotide but inducing distinct clinical outcomes. In this review, we bring together a comprehensive analysis of $\mathrm{CDH} 1$-associated disorders and germline alterations found in each trait, providing important insights into the biological mechanisms underlying E-cadherin's pleiotropic effects. Ultimately, this knowledge will impact genetic counselling and will be relevant to the assessment of risk of cancer development or congenital malformations in $\mathrm{CDH} 1$ mutation carriers.

\section{INTRODUCTION}

The human CDH1 gene codes for E-cadherin (ENSG00000039068), a cell-cell adhesion glycoprotein that acts as a critical invasion suppressor. ${ }^{12}$ During embryonic development, E-cadherin is the first adhesion molecule expressed at the 8-cell stage and is essential for the compaction of the morula and subsequent organisation of epithelial tissues. ${ }^{3}$ Homozygous E-cadherin -/- embryos show severe abnormalities before implantation and do not survive beyond the blastocyst stage. ${ }^{4}$ In adult epithelia, E-cadherin is crucial for the establishment and maintenance of tissue architecture and homeostasis. ${ }^{12}$ E-cadherin function is primarily achieved by homophilic binding of the extracellular domain of cadherins presented on neighbouring cells, forming adherens junctions. ${ }^{5}$ Furthermore, the cytoplasmic domain of E-cadherin is connected to the actin cytoskeleton through various catenins $(\alpha, \beta$ and $\mathrm{p} 120)$, providing cell structural properties while mediating cellular signalling. ${ }^{67} \mathrm{We}$ and others have demonstrated that E-cadherin regulates basic cellular processes such as proliferation, migration, apoptosis and invasion by orchestrating several proteins, namely Hippo and Src family kinase, and signalling pathways involving epidermal growth factor receptor, Notch, Integrin and Laminin. ${ }^{8-12}$

Given the key role of E-cadherin in tissue homeostasis, the deleterious effects that can arise from E-cadherin loss are not surprising. Loss-of-function germline mutations in the $\mathrm{CDH} 1$ tumour-suppressor gene were first described in 1998 as the cause of hereditary diffuse gastric cancer (HDGC) syndrome (OMIM \#137215). ${ }^{13}$ Since the initial report by Guilford et al, many studies have emerged supporting those findings and revealing that HDGC is a rare autosomal dominant disorder that encompasses an increased risk of two cancer types: diffuse gastric cancer (DGC) and lobular breast cancer (LBC) ${ }^{14-17}$ Although DGC is the dominant tumour type in HDGC, other malignant neoplasms, as well as congenital malformations, have been described in families affected by this syndrome (figure 1). ${ }^{17-21}$ For that reason, LBC and oral facial clefts (OFCs) have been suggested as early indicators for $\mathrm{CDH} 1$ screening and early detection of HDGC. ${ }^{21}$

Interestingly, with the scientific and technological advances of massive parallel sequencing and the availability of genetic panel testing, a growing body of evidence suggests that $\mathrm{CDH} 1$ germline mutations are causative of a disease spectrum independent of the HDGC manifestation. ${ }^{19}{ }^{22-25}$ Consequently, we propose that $C D H 1$ is a pleiotropic gene responsible for distinct clinical phenotypes.

In this report, we performed a comprehensive overview of the diseases most frequently associated with $\mathrm{CDH} 1$ germline alterations, as well as the type and functional consequences of the mutations found in each setting, which ultimately can provide important insights into the mechanisms underlying this phenomena. For that purpose, data were collected in the PubMed platform, using single or combined search terms such as $C D H 1$, E-cadherin, $\mathrm{CDH} 1 / \mathrm{E}$-cadherin germline mutations, $\mathrm{CDH} 1 / \mathrm{E}-$ cadherin variants, gastric cancer, $\mathrm{CDH} 1$ susceptibility, familial gastric cancer and HDGC, LBC, colorectal cancer (CRC), cleft lip/palate $(\mathrm{CL} / \mathrm{P})$, blepharocheilodontic syndrome (BCDS) and E-cadherin signalling. Available literature from April 1985 to September 2018 was selected and extensively scrutinised. 


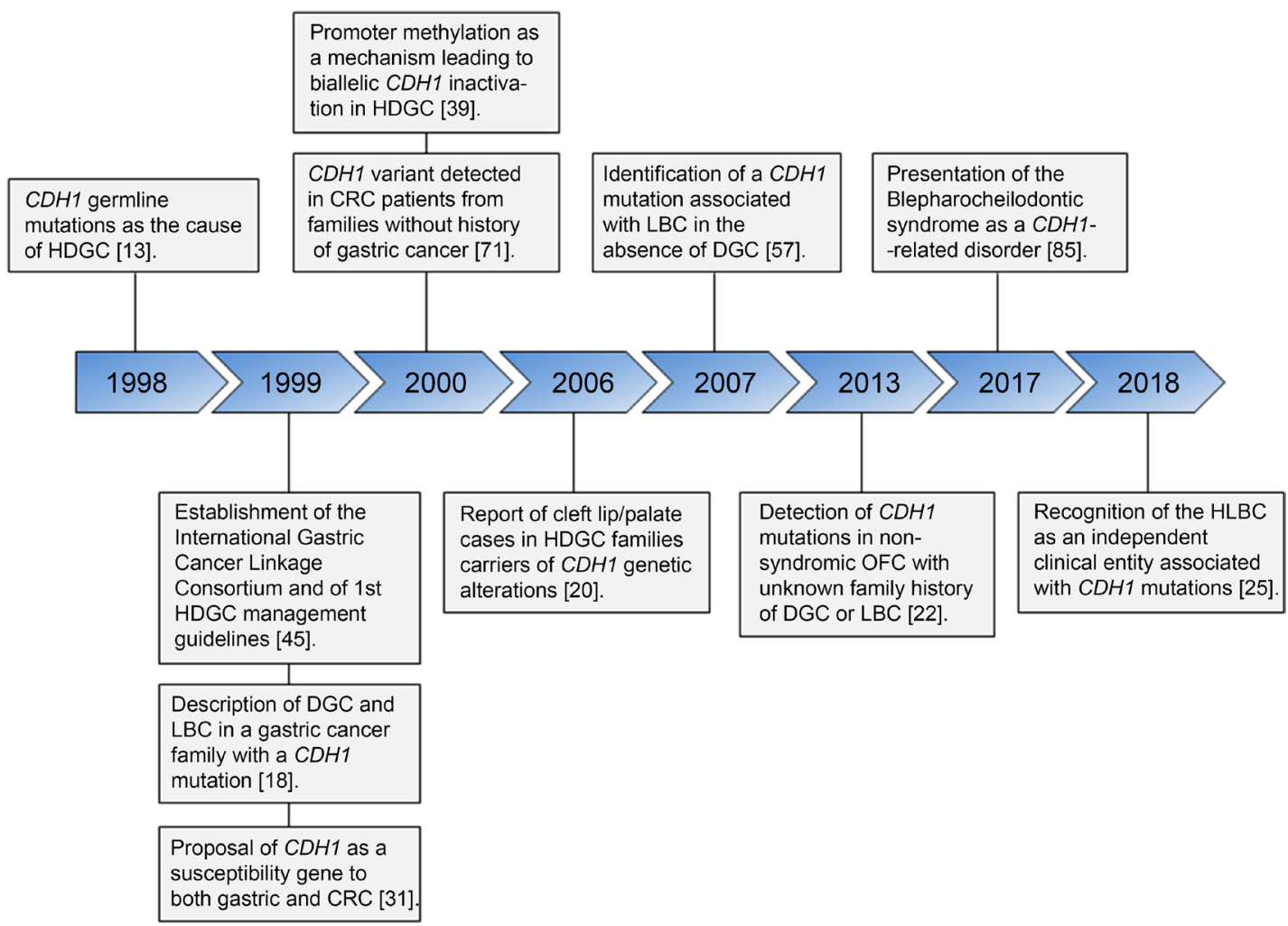

Figure 1 Timeline presenting the key findings related to the clinical phenotypes of $C D H 1$ germline mutation carriers. CRC, colorectal cancer; DGC, diffuse gastric cancer; HDGC, hereditary diffuse gastric cancer; HLBC, hereditary lobular breast cancer; LBC, lobular breast cancer; OFC, oral facial cleft.

\section{Hereditary diffuse gastric cancer}

Defects in the $\mathrm{Ca}^{2+}$-dependent transmembrane protein E-cadherin are frequently associated with several human cancer types, in particular with gastric cancer. The major inherited form of gastric cancer, HDGC, was first identified in a large indigenous New Zealand Māori kindred with a causative germline mutation in $\mathrm{CDH} 1{ }^{13}$ It is well established that $\mathrm{CDH} 1$ inactivating germline mutations underlie this highly penetrant cancer syndrome and are found in approximately $40 \%$ of families meeting the clinical criteria for HDGC. ${ }^{14} 151721$ 26-29 Of relevance, along with a strong aggregation of DGC cases, many HDGC families are also affected by LBC. Accordingly, the cumulative incidence of DGC by 80 years for CDH1 mutation carriers is estimated at $70 \%$ for male and $56 \%$ for females, and the probability of women developing LBC is $42 \% .{ }^{16}{ }^{21}$ CRC, appendiceal signet ring cell carcinomas (SRCCs) and CL/P have also been described in HDGC kindred. ${ }^{15} 17202630-33$ However, of these clinical manifestations, $\mathrm{CL} / \mathrm{P}$ is the only one considered within the HDGC clinical definition. ${ }^{21}$

In the HDGC clinical setting, $C D H 1$ germline abnormalities are evenly distributed throughout the gene with no apparent genotype-phenotype correlation established. ${ }^{34}$ The great majority of the published germline mutations are expected to lead to truncated proteins or lack of mRNA expression, allowing a straightforward prediction of their pathogenicity. ${ }^{1629}$ The most common mutation types are small insertions or deletions $(38 \%) .{ }^{16}$ Others vary between splice site $(21 \%)$, nonsense $(17 \%)$ and large exonic deletions $(9 \%) .{ }^{16}$ The missense fraction accounts for $16 \%$ of the mutations described so far. ${ }^{16} 35$ The clinical and functional impact of missense mutations still raises controversy among specialists because, in most cases, a full-length protein is preserved, and regular levels of E-cadherin expression are usually produced. ${ }^{35} 36$ As such, the identification of a $\mathrm{CDH} 1$ missense variant requires additional studies to determine E-cadherin functional status and, consequently, its putative pathogenicity. $^{21} 283537$

The type and frequency of germline defects in HDGC families are constantly being re-evaluated. The latest review points to a total of 155 germline $C D H 1$ mutations described across multiple ethnicities. ${ }^{1621}$ Most are considered pathogenic (126/155), while a small proportion cannot be categorised in terms of their functional relevance $(29 / 155)$ and are termed variants of uncertain significance (VUSs). ${ }^{16}$ Newly revised criteria and new methodological approaches to predict their pathogenic nature are thus needed for an improved classification system.

As an autosomal-dominant familial disorder, HDGC CDH1 mutations are inherited in only one allele. For initiation of the neoplastic process, somatic inactivation or downregulation of the second copy of the CDH1 gene must occur. ${ }^{38-41}$ Epigenetic causes seem to play an essential role in this process. Promoter hypermethylation is the most common established mechanism leading to biallelic $\mathrm{CDH} 1$ inactivation, while mutation or deletion of the second $\mathrm{CDH} 1$ allele is less frequently described. ${ }^{38-41}$

The disease originates with the development of early gastric lesions characterised by spreading of isolated malignant cells. ${ }^{42}$ Precursor lesions of invasive gastric cancer have been identified as in situ SRCC or pagetoid spread of signet ring cells below the preserved epithelium. ${ }^{342}$ The pathology of such lesions is unique but not easy to recognise; therefore, their examination and confirmation by experienced pathologists is highly recommended. The presence of in situ lesions, pagetoid spread or multifocal intramucosal signet ring cells in the gastric mucosa provides substantial clues for the diagnosis and management of patients with HDGC, as well as for research. ${ }^{43}$ It is feasible that many in situ/early invasive lesions are transient, or remain indolent, and do not progress towards an advanced stage. ${ }^{43} 44$ 
Unfortunately, progression to invasive or advanced disease is unpredictable, limiting the utility of scheduled patient follow-up and surveillance. In light of the invasive and lethal nature of diffuse gastric carcinomas and the high degree of penetrance of CDH1 mutations, prophylactic total gastrectomy remains the recommended risk-reducing approach for HDGC family mutation carriers. ${ }^{1630}$

Recognition of the need for common terminology and management guidelines for this syndrome led to the establishment of the International Gastric Cancer Linkage Consortium, constituted by a multidisciplinary team of experts in $1999 .{ }^{45}$ Over the last 19 years, this collaborative group, which includes gastroenterologists, oncologists, surgeons, pathologists, geneticists, nutritionists and molecular biologists, has been defining and improving the clinical criteria for early diagnosis of the disease and the identification of patients who should undergo germline $\mathrm{CDH} 1$ genetic screening. ${ }^{214647}$ The latest revised criteria indicate that CDH1 testing should be applied in any case fulfilling one of the following criteria: (1) families with two or more documented cases of gastric cancer at any age, one with confirmed DGC; (2) personal history of DGC before the age of 40 years; and (3) personal or family history of DGC and LBC, with one diagnosed before the age of 50 years. ${ }^{21}$ Testing could also be considered in: (1) cases of bilateral LBC or family history of two or more cases of LBC, before the age of 50 years; (2) a personal or family history of CL/P in a patient with DGC; and (3) in situ signet ring cells and/or pagetoid spread of signet ring cells, as this feature is rarely seen in sporadic cases. ${ }^{21}$ Whenever possible, testing should start in an affected proband. If the affected proband is deceased, frozen-fixed or formalin-fixed, paraffin-embedded tissue (preferably normal, non-malignant tissue) may still be used as an alternative. ${ }^{21} 37$

As noted above, carriers of $\mathrm{CDH} 1$ pathogenic mutations are advised to undergo a total prophylactic gastrectomy, regardless of the negative endoscopic findings. ${ }^{48}{ }^{49}$ Some patients delay this decision due to personal, physical or psychological reasons and, in these cases, annual endoscopic surveillance should be employed. ${ }^{21}$ Approximately $60 \%$ of families that fulfil the current testing criteria for HDGC lack germline $\mathrm{CDH} 1$ mutations. ${ }^{16} 1950$ These families remain genetically unexplained and may carry pathogenic mutations in other, yet unknown, gastric cancer susceptibility genes. Patients fulfilling the HDGC criteria, who have tested negative for $\mathrm{CDH} 1$ germline mutations, are advised to undergo intensive endoscopic screening with gastroenterologists familiar with HDGC. ${ }^{21}$ The same protocol should be followed by $\mathrm{CDH} 1$ VUS carriers. ${ }^{21}$ Importantly, all individuals undergoing endoscopic examination must be aware that it is possible that lesions at early stage will not be detected by random biopsies due to the multifocal nature of the disease. ${ }^{42} 4851$ In addition, bilateral MRI of the breast, starting at age of 30 years, is recommended annually in women with a CDH1 mutation. ${ }^{21}$

The CTNNA1 gene, which encodes for $\alpha$-E-catenin, is a strong candidate to explain a minor portion of $C D H 1$-negative HDGC families. Aside from its crucial role in E-cadherin-mediated adhesion, CTNNA1 has been found to be mutated in five HDGC families (five distinct mutations), corroborating the functional significance of $\mathrm{CDH} 1$ mutations and the importance of E-cadherin downstream signalling. ${ }^{165253}$ Despite all the recent efforts in pursuing new candidate genes, $\mathrm{CDH} 1$ genetic alterations remain the central cause of HDGC. 52 54-56

\section{LBC and hereditary lobular breast cancer (HLBC)}

Most hereditary cancer syndromes display specific organ sites preferentially affected by cancer. In this regard, LBC is the second most frequent cancer type associated with HDGC. ${ }^{18}{ }^{19}$ In 2013, a study was carried out in 165 unrelated Ile-de-France index cases, selected based on personal and family history of gastric or breast cancers, and it was shown that 18 cases $(11 \%)$ were $C D H 1$ germline mutation carriers (18 different mutations). ${ }^{19}$ Three of the carriers were women with a personal history of bilateral LBC below 50 years of age. None of these cases presented family history of DGC in first-degree and second-degree relatives, and as such, they did not meet the HDGC criteria established at that time. ${ }^{1947}$ Two of those women were subsequently diagnosed with DGC, while the third woman was subjected to upper gastrointestinal endoscopy with multiple biopsies. Despite no cancer foci being found in the biopsies, the patient underwent prophylactic gastrectomy, and an invasive DGC was identified. ${ }^{19}$

Remarkably, in the last few years, a number of studies have arisen reporting early-onset LBC cases in CDH1 mutation carriers without any personal or family history of DGC, pinpointing $\mathrm{CDH} 1$ as a novel LBC-susceptibility gene. ${ }^{23}$ 57-60 Moreover, HLBC was recently proposed to be an independent clinical entity associated with $\mathrm{CDH} 1$ germline alterations. ${ }^{25} 58$ According to the HDGC consensus guidelines, women diagnosed with bilateral LBC, with or without family history of LBC before the age of 50 years, or women diagnosed with unilateral LBC with family history of LBC with onset age at less of 45 years, are eligible for $\mathrm{CDH} 1$ genetic testing. ${ }^{25}$

Currently, there are four high-penetrance genes identified to be genetically associated with increased breast cancer susceptibility: BRCA1, BRCA2, TP53 and CDH1. Germline mutations in BRCA1 and TP53 are predominantly associated with invasive ductal carcinoma, BRCA2 mutations are associated with both ductal and lobular tumours, while mutations in $C D H 1$ are exclusively associated with LBC, in particular with the invasive subtype. ${ }^{61}$

Invasive $\mathrm{LBC}$ is the second most common histological type of breast cancer, accounting for $5 \%-15 \%$ of invasive breast cancers, and is one of the few histological subtypes harbouring a distinct genetic alteration that is associated with a specific phenotype. ${ }^{62}$ Indeed, around $90 \%$ of invasive LBC display E-cadherin loss, either at the DNA, mRNA or protein level and, in the few tumours preserving expression, E-cadherin integrity is nonetheless impaired. ${ }^{63}{ }^{64}$ In contrast, E-cadherin expression is usually unaffected in ductal breast carcinomas. ${ }^{65}$ Thus, E-cadherin decreased expression can be used as a molecular marker to distinguish ductal from lobular carcinomas.

Loss of E-cadherin expression contributes to the unique histopathological features shared by DGC and LBC. These tumours do not form a well-defined mass and are composed of relatively small, infiltrating and dyshesive epithelial cells, showing a high predisposition to metastasise to the gastrointestinal tract, gynaecological organs, meninges and peritoneal surface, resembling the DGC cells phenotype. ${ }^{6667}$

Common to both cancer types is also the fact that $\mathrm{CDH} 1 \mathrm{germ}$ line mutations occur across the entire gene coding sequence. ${ }^{25} 34$ However, the type and frequency of the genetic alterations differ, with missense mutations constituting the most frequent alteration in HLBC. ${ }^{25}{ }^{34}$ Of the 16 novel germline $\mathrm{CDH} 1$ variants that have been identified in families with LBC alone, there were six missense mutations $(37.5 \%)$, three splice site mutations (18.7\%), three deletions (18.7\%), two insertions (13\%), one nonsense mutation (6.2\%) and one premature stop codon 
Table 1 CDH1 variants identified in patients with colorectal cancer (CRC)

\begin{tabular}{|c|c|c|c|c|c|c|}
\hline Alteration & Location & Type & Families & CRC cases & Other tumours & References \\
\hline c.45_46insT (p.Gln16Serfs*18) & Exon 1 & Frameshift & 1 & 2 & HDGC and LBC. & 33 \\
\hline c. $49-2 A>G$ & Intron 1 & Splice site & 1 & 1 & HDGC and lung. & 31 \\
\hline c. $49-2 \mathrm{~A}>\mathrm{C}$ & Intron 1 & Splice site & 1 & 1 & $\begin{array}{l}\text { Breast, skin prostate, bladder, pancreas } \\
\text { and throat. }\end{array}$ & 27 \\
\hline c. $1008 \mathrm{G}>\mathrm{T}$ & Exon 7 & Splice site & 1 & 2 & HDGC. & 13 \\
\hline c.1018A>G (p.Thr340Ala) & Exon 8 & Missense & 2 & 2 & HDGC $\dagger$ and ovary. $\dagger$ & $7133 t$ \\
\hline c.1225T>C (p.Trp409Arg) & Exon 9 & Missense & 1 & 1 (SRCC) & DGC. & 15 \\
\hline $\begin{array}{l}\text { c.1774G }>\text { A } \\
\text { (p.Ala592Thr)* }\end{array}$ & Exon 12 & Missense & 2 & 3 & DGC and breast andrenal. & $7269+$ \\
\hline
\end{tabular}

For each mutation, the affected site, type of mutation, number of families and carriers affected by CRC and other tumours described in the same genetic background are assigned.

${ }^{*}$ Classified as non-pathogenic in ref 69.

†Described elsewhere.

DGC, diffuse gastric cancer; HDGC, hereditary diffuse gastric cancer; LBC, lobular breast cancer; SRCC, signet ring cell carcinoma.

(6.2\%) (reviewed in $\operatorname{ref}^{25}$ ). Strikingly, five of these mutations have been previously detected in HDGC families, indicating that the same genetic alteration may induce distinct clinical outcomes in different genetic backgrounds and that other factors may have a role in the aetiology of both diseases. ${ }^{14} 2331596068-70$

\section{CRC reports in $\mathrm{CDH} 1$ germline mutation carriers}

It has long been speculated that $\mathrm{CDH} 1$ mutations could also predispose to other epithelial cancers. Indeed, some studies have reported cases of CRC in CDH1 mutation carriers. ${ }^{31} 4571$ However, the inclusion of CRC as part of the HDGC disease spectrum is still controversial mostly due to the fact that only a small number of cases have been identified in HDGC families.

The proposal of a role for CDH1 in early onset CRC, and as a cause of inherited susceptibility to both gastric cancer and CRC, dates back to 1999 , when an early report described a CDH1 mutation carrier (c.49-2A $>$ G) who developed CRC at the age of 30 years (table 1). ${ }^{31}$ In 1998, Guilford et $a l^{13}$ had also identified two individuals harbouring $\mathrm{CDH} 1$ mutations, aged 30 years and 74 years, affected by CRC in a gastric cancer kindred. Furthermore, the retrospective analysis of eight families with inactivating germline $\mathrm{CDH} 1$ mutations suggested that CRC screening and counselling should be considered as the risk to develop CRC might be increased. ${ }^{45}$ In subsequent years, other studies emerged in which patients with CRC were identified in families with or without history of gastric cancer or E-cadherin germline mutations. ${ }^{27} 3033$ Notably, on stratification of patients with CRC, the CDH1 c.1018A>G (p.Thr340Ala) missense variant was detected in two patients with CRC from families lacking gastric cancer cases, reinforcing that E-cadherin dysregulation may contribute to CRC development. ${ }^{71}$ In addition, the identification of a CDH1 missense mutation (c.1774G $>\mathrm{A} / \mathrm{p}$. Ala592Thr) in two patients with colon cancer, from a family presenting segregation of this alteration with DGC and CRC, further suggested it could be implicated in CRC. ${ }^{72}$ Interestingly, some patients were identified with carcinomas with signet ring cell features, as usually observed in HDGC. An individual with SRCC of the colon was identified in a family with the $1225 \mathrm{~T}>\mathrm{C}$ (p.Trp409Arg) E-cadherin missense mutation, ${ }^{15}$ and a primary appendiceal SRCC was described in a $C D H 1$-associated HDGC kindred with synchronous primary DGC. ${ }^{32}$ Altogether, at least 12 patients (seven distinct mutations) have already been identified with CDH1-associated CRC from nine families of distinct origins. However, in most cases, the number of patients with CRC identified in these families is not sufficient to include CRC screening in the surveillance of $C D H 1$ mutation carriers.
The involvement of CDH1 in CRC development has received some support from studies unrelated to HDGC. More specifically, a meta-analysis of genome-wide association data identified the E-cadherin locus as a new susceptibility factor for developing CRC. ${ }^{73}$ In an attempt to identify additional CRC cases with familial predisposition, comprehensive screening for mutations associated with CRC was performed in 152 patients, resulting in the identification of a single $C D H 1$ mutation. ${ }^{74}$ In another report, a $C D H 1$ polymorphism was also shown to be a risk factor for CRC development. ${ }^{75}$ Noteworthy, a large-scale study identified three new susceptibility loci, including the CDH1 locus, in patients with ulcerative colitis (a common form of inflammatory bowel disease). ${ }^{76}$ These data reinforce that disruption of E-cadherin could also lead to distinct alterations in the colon epithelia, from benign to malignant lesions, though this is a rare event.

Overall, the evidence implicating $\mathrm{CDH} 1$ germline mutations in CRC, either dependent or independent of the HDGC cancer spectrum, is still scarce. Accordingly, in current clinical practice, no recommendations are yet approved for CRC screening in $\mathrm{CDH} 1$ mutation carriers. Future studies will clarify whether CRC occurs occasionally in HDGC families or if it is a bona fide $\mathrm{CDH} 1$-associated disorder.

\section{Cleft lip/palate}

OFCs are a heterogeneous group of congenital disorders that result from complex interactions between genetic and environmental risk factors, which affect the lips and oral cavity, causing isolated cleft palate and cleft lip with or without cleft palate. ${ }^{77}$ Although variable among populations, the incidence of $\mathrm{CL} / \mathrm{P}$ is supposed to be in the range of 1 in 700 to 1 in 1000 newborns, ranking among the most prevalent birth defects. Affected individuals display high morbidity, experiencing severe feeding, hearing, speech and psychological problems. ${ }^{77} 78$ Around 70\% of $\mathrm{CL} / \mathrm{P}$ cases are estimated to be non-syndromic, occurring as isolated entities in the absence of other congenital anomalies and, as such, intensive research has focused in trying to identify candidate genes and the underlying molecular pathways. ${ }^{347}$

The biological implication of E-cadherin dysfunction in the aetiology of non-syndromic OFC comes as no surprise, given its overexpression in the critical stages of lip and palate development, namely in the frontonasal prominence at 4 and 5 weeks of embryogenesis and in the lateral and medial nasal prominences at 6 weeks. ${ }^{20}$ The increased incidence of CL/P cases in CDH1 mutation carriers, when compared with that in the general population, further supports the involvement of E-cadherin in the molecular basis of this congenital defect. 
In 2006, it was first reported the association of two different splice site CDH1 mutations, both affecting the E-cadherin extracellular domain, with OFC in two HDGC families. ${ }^{20}$ These findings were subsequently corroborated by Kluijt and coworkers, ${ }^{17}$ who described three variants associated with seven cases of $\mathrm{CL} / \mathrm{P}$ in Dutch HDGC families carrying CDH1 germline mutations.

Ever since, many studies have shed light on the nature of $\mathrm{CDH} 1$ mutations associated with $\mathrm{CL} / \mathrm{P}$ cases, their penetrance and to what extent the types of mutations or mechanisms lead to either cancer, $\mathrm{CL} / \mathrm{P}$ or both phenotypes. In a cohort of 81 children with non-syndromic OFC, Vogelaar and coworkers ${ }^{22}$ identified three $C D H 1$ missense mutations shown to be functionally relevant in four patients with unknown family history of DGC or LBC. Through exome sequencing, Bureau et $a^{79}$ were also able to identify one common damaging $\mathrm{CDH} 1$ mutation in three distant relatives affected with non-syndromic OFC, further highlighting the contribution of E-cadherin dysfunction in the genesis of this congenital defect. However, the definite proof came out when 221 Brazilian probands were sequenced and, when compared with that of non-familial controls, an overall increased $\mathrm{CDH} 1$ mutational burden among probands from non-syndromic CL/P families was found. ${ }^{24}$ Ultimately, this study was able to establish a consistent role of rare, moderately penetrant, loss of function $\mathrm{CDH} 1$ variants in OFC. ${ }^{24}$ Indeed, the penetrance of $\mathrm{CL} / \mathrm{P}$ in $\mathrm{CDH} 1$ mutation carriers has been correlated with $\mathrm{CDH} 1$ promoter methylation arising as a second hit. ${ }^{80}$

Very recently, a large whole-exome sequencing study in a cohort of 72 multigenerational families with non-syndromic $\mathrm{CL} / \mathrm{P}$ revealed 10 pathogenic or likely pathogenic variants in five different genes, CDH1 (2), CTNND1 (5), PLEKHA7 (1), PLEKHA5 (1) and ESRP2 (1), which are functionally linked in the assembly of the epithelial cadherin/catenin complex. ${ }^{81}$ These genes were targeted for sequencing in a second non-syndromic $\mathrm{CL} / \mathrm{P}$ cohort of 497 individuals from 444 families and 10 distinct mutations were identified, providing undisputable evidence for the role of E-cadherin and epithelial adhesion in the molecular mechanism underlying OFC. ${ }^{81}$ Notably, the $C D H 1$ variants identified in this study were present in individuals with $\mathrm{CL} / \mathrm{P}$ alone, with a single exception in a family where one case of gastric cancer was recently diagnosed. ${ }^{81}$

Other association studies have also described $\mathrm{CDH} 1$ polymorphisms associated to non-syndromic CL/P. In a Brazilian study, involving 500 individuals with non-syndromic clefts and an equal number of unrelated controls, an association between two genetic variants in $\mathrm{CDH} 1$ and susceptibility to non-syndromic $\mathrm{CL} / \mathrm{P}$ was found ${ }^{82} \mathrm{~A}$ couple of years later, Song and Zhang ${ }^{83}$ revealed that the specific single nucleotide polymorphism rs16260 (C>A), located upstream of the transcriptional start site of the $\mathrm{CDH} 1$ promoter, was associated with an increased risk of cleft palate alone in a Chinese Han population.

To date, 23 different CDH1 mutations have been reported in the literature associated with $\mathrm{CL} / \mathrm{P}$, seven of which were described in families also segregating gastric cancer (table 2). Of note is the fact that among the $\mathrm{CDH} 1$ mutational repertoire, some mutations increase the risk of $\mathrm{CL} / \mathrm{P}$ alone, whereas others increase the risk of gastric cancer too. While it is plausible that CDH1 mutations leading to higher invasiveness (in vitro) could increase the risk of gastric cancer, it has been speculated that haploinsufficiency during critical stages of embryonic development could lead to OFC. ${ }^{24}$ The current landscape of $\mathrm{CDH} 1$ germline mutations associated with gastric cancer, $\mathrm{CL} / \mathrm{P}$ or both, does not suggest any preferential type or location of $\mathrm{CDH} 1$

Table 2 CDH1 mutations found in patients affected by cleft lip/palate (CL/P)

\begin{tabular}{|c|c|c|c|c|c|}
\hline Alteration & Location & Type & $\mathrm{CL} / \mathrm{P}$ cases & Cancer history & References \\
\hline $\begin{array}{l}\text { c.88C }>\text { A } \\
\text { (p.Pro30Thr) }\end{array}$ & Exon 2 & Missense & 2 & ${ }^{\mathrm{a} H D G C} ;{ }^{*}{ }^{\mathrm{b}} 2 \mathrm{LBC}{ }^{*}$ & $22,{ }^{a} 98^{*},{ }^{b} 59^{*}$ \\
\hline c.337A>G (p.Lys113Glu) & Exon 3 & Missense & 1 & & 22 \\
\hline c. $387+5 G>A$ & Intron 3 & Splice site & 1 & & 24 \\
\hline c. $531+2 \mathrm{~T}>\mathrm{A}$ & Intron 4 & Splice site & 4 & 3DGC; $1 \mathrm{GC}$ & 20 \\
\hline c. $531+3 A>G$ & Intron 4 & Splice site & 1 & & 22 \\
\hline$c .532-18 C>T$ & Intron 4 & Splice site & 3 & $1 \mathrm{DGC}^{*} ; 1$ mixed $\mathrm{GC}^{*}$ & $2228^{*}$ \\
\hline c. $752 \mathrm{C}>\mathrm{T}$ (p.Thr251Met) & Exon 6 & Missense & 1 & & 81 \\
\hline c.760G >A (p.Asp254Asn) & Exon 6 & Missense & $8+1^{*}$ & & $24,81^{*}$ \\
\hline c.768T>A (p.Asn256Lys) & Exon 6 & Missense & 6 & & 81 \\
\hline$c .832+1 \mathrm{G}>\mathrm{T}$ & Intron 6 & Splice site & 1 & 1DGC & 99 \\
\hline c. $1023 \mathrm{~T}>\mathrm{G}(\mathrm{p} . \mathrm{Tyr} 341$ *) & Exon 8 & Nonsense & 5 & $\mathrm{HDGC}^{*}$ & $24,100^{*}$ \\
\hline c.1108G >T (p.Asp370Tyr) & Exon 8 & Missense & 1 & & 22 \\
\hline c.1135_1137+5delins5 & Exon 8 & Splice site & 1 & $4 \mathrm{GC}$ & 17 \\
\hline c. $1137 \mathrm{G}>\mathrm{A}$ & Exon 8 & Splice site & 1 & $2 \mathrm{DGC} ; 1 \mathrm{GC}$ & 20 \\
\hline c.1404delC (p.Thr468Thrfs*13) & Exon 10 & Frameshift & 3 & $9 \mathrm{GC} ; 1 \mathrm{BC}$ & 17 \\
\hline c.1489G>A (p.Glu497Lys) & Exon 10 & Missense & 1 & & 81 \\
\hline c.1766A>T (p.Asn589lle) & Exon 12 & Missense & 1 & & 81 \\
\hline c.2143G>T (p.Gly715*) & Exon13 & Nonsense & 3 & & 79 \\
\hline c.2351G >A (p.Arg784His) & Exon 15 & Missense & 3 & & 24 \\
\hline c.2413G>A (p.Asp805Asn) & Exon 15 & Missense & 1 & $1 \mathrm{DGC}^{*}$ & $22,16^{*}$ \\
\hline c.2426_2427del (p.Asn809llefs*3) & Exon 15 & Frameshift & 4 & & 81 \\
\hline c. $2439+10 C>T$ & Intron 15 & Splice site & 1 & & 22 \\
\hline c.2440-6_2440-4del & Intron 15 & Splice site & 1 & & 22 \\
\hline
\end{tabular}

The genetic alteration, mutation type, number of CL/P cases and reports of associated cancers are presented.

*Described elsewhere.

HDGC, hereditary diffuse gastric cancer; LBC, lobular breast cancer; DGC, diffuse gastric cancer; GC, gastric cancer; $B C$, breast cancer. 


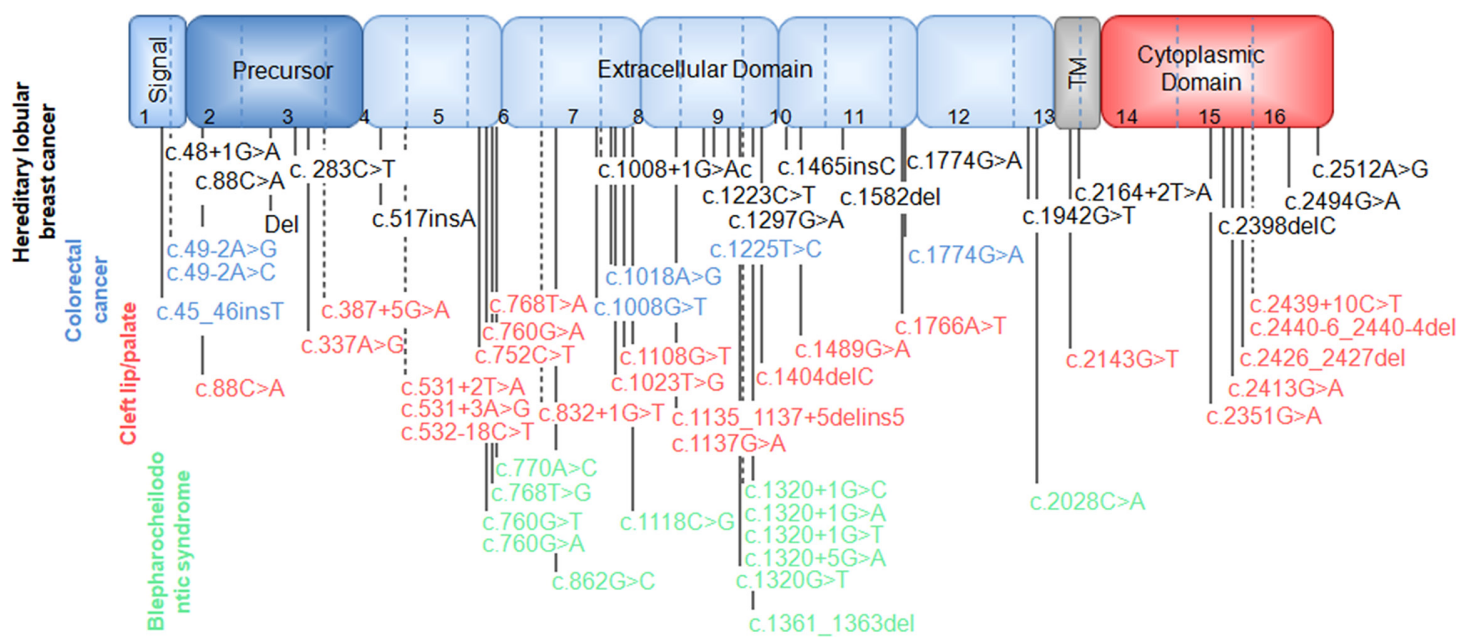

Figure 2 Distribution of $C D H 1$ germline mutations identified in the different disorders. The scheme illustrates E-cadherin signal peptide, precursor sequence, extracellular domains, transmembrane domain (TM) and cytoplasmic domain. The location of $C D H 1$ mutations described in lobular breast cancer (black), colorectal cancer (blue), cleft lip/palate (red) and blepharocheilodontic syndrome (green) is represented.

germline mutations along the different domains, preventing any sort of differential patient management (figure 2). Moreover, some expert groups-like the Dutch Working Group on Hereditary Gastric Cancer-believe that future parents of $\mathrm{CDH} 1$ mutation carriers are not required to be informed regarding the risk of $\mathrm{CL} / \mathrm{P}$ in their offspring as an integral part of genetic counselling. ${ }^{17}$ Nonetheless, occurrence of CL/P abnormalities should be reported in families with HDGC history, so careful counselling can be offered. ${ }^{34}$

Considering all the evidence provided throughout the past decades, the contribution of $\mathrm{CDH} 1$ variants to OFC aetiopathology is unquestionable. However, the incomplete penetrance and variable expressivity of non-syndromic CL/P awards this congenital trait with a complexity that needs to be addressed through a multidisciplinary approach.

\section{Blepharocheilodontic syndrome}

Data implicating E-cadherin deregulation in other congenital disorders is growing, further validating the essential role of E-cadherin in human embryological development. BCDS (OMIM \#119580), which is a rare birth disorder, was recently added to the set of CDH1-related diseases (figure 3). ${ }^{84-86}$ This syndrome, first described by Elschnig in 1912, ${ }^{87}$ usually occurs in sporadic patients but is also reported in large non-consanguinous families, suggesting an autosomal dominant segregation. ${ }^{85} 88-91$

BCDS is characterised by bilateral CL/P, which is its major feature, dental anomalies (such as conical teeth and tooth agenesis), hair defects and eyelid malformations, namely ectropion of the lower eyelids, euryblepharon and lagophthalmia. 888992 In addition, other clinical features, such as imperforate anus, neural tube defect, hypothyroidism due to thyroid gland aplasia or hypoplasia and syndactyly have also been reported in a few patients. ${ }^{88} 9091$ Despite the clinical burden and the severe impact on patients' lives, the causes of such complex condition are yet to be uncovered.

In an attempt to understand the molecular basis of this disease, Freitas et al have screened several genes implicated in syndromes with a similar phenotype, namely TP63 and IRF6 (ectodermal dysplasia syndromes), FOXE1 (orofacial clefting associated with thyroid agenesis) and TBX10 and OSR2 (orofacial clefting associated with thyroid agenesis genes). ${ }^{90}$ However, they failed to identify a clear causative mutation. ${ }^{90}$ Interestingly, in 2016,
Nishi et al ${ }^{84}$ identified a CDH1 missense mutation in a patient presenting right choanal atresia and several dysmorphic facial features, such as $\mathrm{CL} / \mathrm{P}$. Subsequently, two other independent studies, published in 2017 and 2018, used an exome sequencing approach on patients with BCDS and also found mutations in $\mathrm{CDH} 1$ and in one other member of the cadherin-catenin complex, CTNND1. Ghoumid et al ${ }^{85}$ described three deletions and two heterozygous missense mutations in the $\mathrm{CDH} 1$ gene, and three CTNND1 truncating mutations, while Kievit's team identified seven $\mathrm{CDH} 1$ variants (four missense and three deletions), as well as two truncating mutations and one missense variant in CTNND1 (table 3). ${ }^{86}$ The first group also detected two asymptomatic parents carrying either a CDH1 or a CTNND1 mutation, suggesting incomplete penetrance of the genotype. ${ }^{85}$
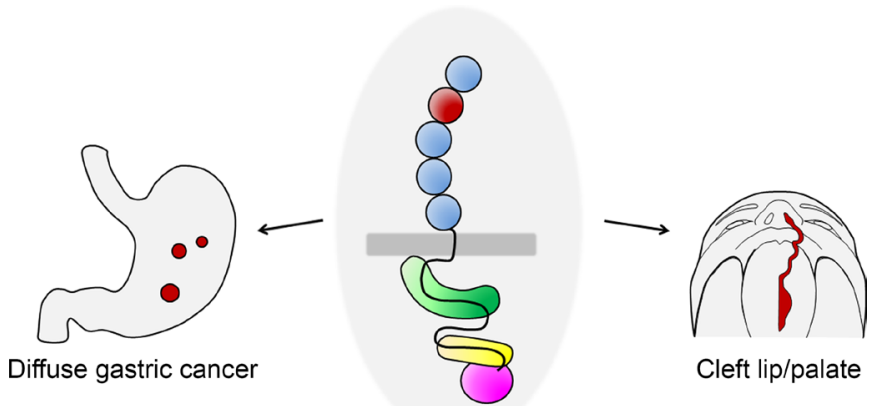

Cleft lip/palate

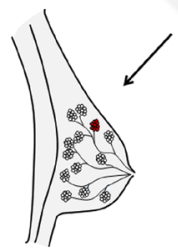

Lobular breast cancer

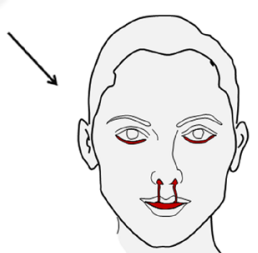

Blepharocheilodontic syndrome
Figure 3 Illustration of E-cadherin pleiotropic effects. $C D H 1$ germline mutations, inducing loss of E-cadherin expression and function, can result in hereditary cancer or congenital malformations. Diseases such as diffuse gastric cancer and lobular breast cancer, as well as cleft lip/palate and the blepharocheilodontic syndrome, constitute the clinical spectrum of $\mathrm{CDH} 1$ mutation carriers. 
Table 3 CDH1 and CTNND1 mutations found in patients with the blepharocheilodontic syndrome (BCDS)

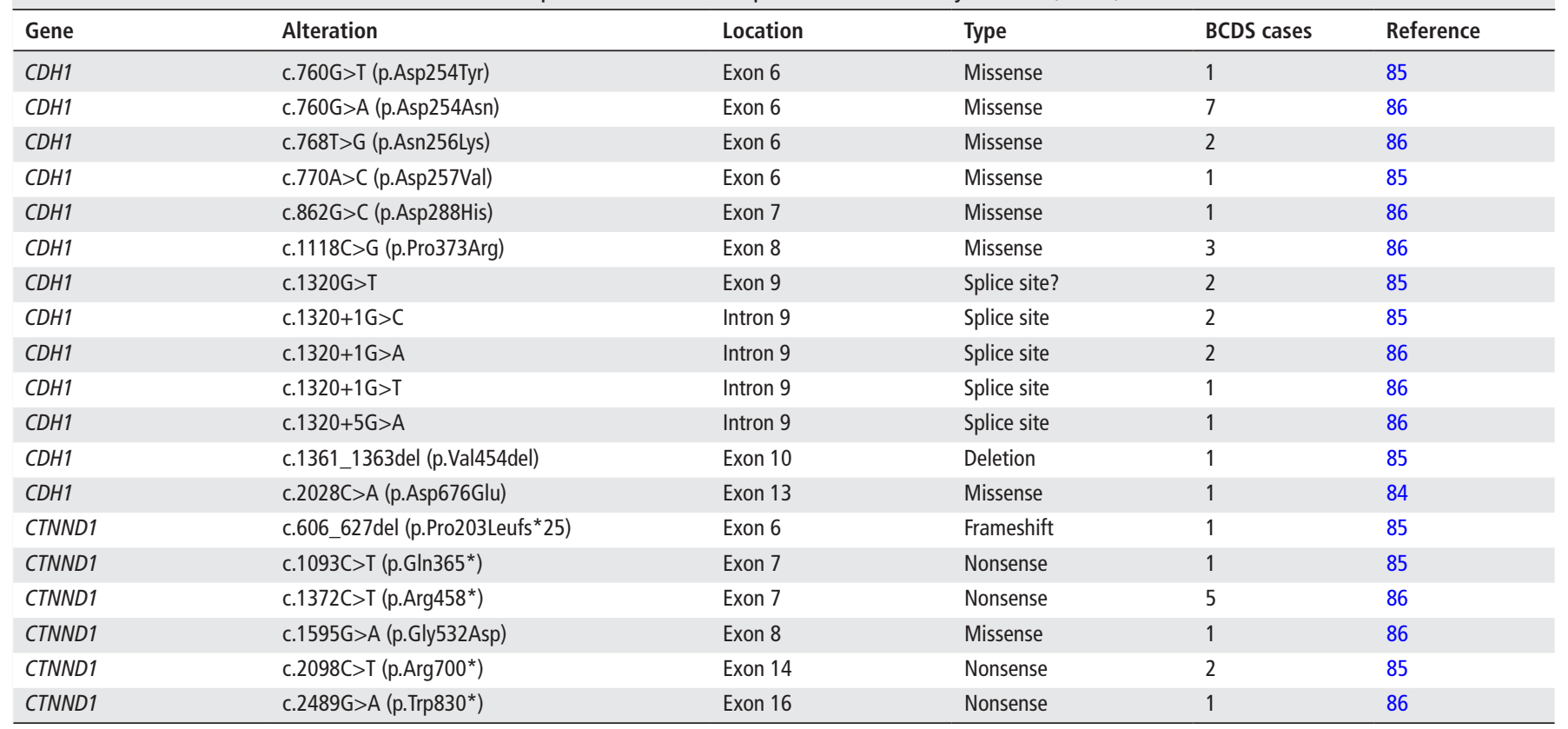

For each genetic alteration, the location, type of mutation, number of BCDS cases, as well as the corresponding reference are displayed.

Of note, all CDH1 mutations described in this context affect the E-cadherin extracellular domain, possibly impairing its ability to homodimerise and, consequently, interfering with its adhesive function. ${ }^{85} 86$ In particular, both studies detected missense mutations at the conserved Asp254-Gln255-Asn256-Asp257 'linker' region that comprises a calcium ion-binding site between extracellular domains 1 and $2 .{ }^{8586}$ As a result, the interaction of these residues with calcium ions may be disrupted, perturbing protein conformation. The $\mathrm{CDH} 1$ splice site variant c. $1320+1 G>C$ disturbs the consensus donor motif AGgt, which is critical for splicing, and induces exon 9 skipping. ${ }^{85}$ This leads to the removal of a major portion of the extracellular domain 3 (EC3), impairing its function. ${ }^{85}$ Furthermore, the mutation c.1361_1363del (p.Val454del) removes the hydrophobic cluster located at the c-terminal region of a beta-strand of the EC3 domain. ${ }^{85}$

While Ghoumid et al reported that BCDS CDH1 missense variants behave similarly to HDGC-associated ones, with perinuclear accumulation and accelerated E-cadherin degradation, Kievit et al described a dominant negative effect of BCDS CDH1 variants. ${ }^{85}$ The researchers transfected cells with GFP-WT CDH1 and different SNAP-tagged CDH1 variants (including two HDGC-related mutations for comparison) and observed that, in the case of BCDS variants, mutant proteins dimerise with WT proteins and interfere with the formation of adherens junctions, impairing cell-cell adhesion. ${ }^{86}$

The CTNND1 truncating variants affect p120-catenin isoforms $1-3 .{ }^{85}$ These mutations result in premature stop codons, which activate the nonsense-mediated RNA decay mechanism, leading to mRNA degradation and subsequent haploinsufficiency. ${ }^{85} 86$ Kievit et al also identified a missense mutation that affects the highly conserved $\mathrm{H} 3$ helix in the fifth armadillo repeat of CTNND1, which is essential for the interaction between p120-catenin and E-cadherin's cytoplasmic tail. ${ }^{8693}$ The disruption of p120-catenin/E-cadherin binding destabilises E-cadherin at the membrane and makes E-cadherin available for interaction with proteins from the endocytic machinery, like clathrin adapter proteins and Hakai, that target E-cadherin for degradation. ${ }^{94}$ Although no genotype-phenotype correlation was found, a general observation from both studies was that patients with CTNND1 mutations have milder symptoms when compared with patients with $\mathrm{CDH} 1$ variants. ${ }^{85} 86$ For example, clefting is less frequent, as is hypothyroidism, neural tube defects and imperforate anus. ${ }^{86}$ In the cases where neither $C D H 1$ nor CTNND1 mutations were detected, patients have even less severe features. $^{86}$

Taking these findings into account, it is clear that the function of E-cadherin goes far beyond its invasion and tumour suppressor role. Abnormal E-cadherin expression and signalling can drive the formation of irregular morphological structures, such as defects of palate, lips, eyelids, teeth and neural tube, expanding the clinical spectrum of $\mathrm{CDH} 1$-associated diseases to severe congenital malformations.

\section{CONCLUSION}

Compelling evidence suggests that $\mathrm{CDH} 1 / \mathrm{E}$-cadherin is involved in multiple tissue processes, and its dysfunction can result in a plethora of clinical manifestations. It is now widely accepted that DGC and LBC, as well as congenital malformations, such as $\mathrm{CL} / \mathrm{P}$ and BCDS, are part of the CDH1-disease spectrum. Thus, $\mathrm{CDH} 1$ is emerging as a pleiotropic gene.

Pleiotropy is the phenomenon by which the same gene can result in a plethora of effects. In fact, 16.9\% of genes and $4.6 \%$ of genetic variants have pleiotropic consequences, as shown by the GWAS catalogue. ${ }^{95}$ Although the occurrence of pleiotropy is a central phenomena for evolution and has been recognised for over 100 years, the mechanisms by which a single gene can affect multiple traits are still far from being fully understood. Several mechanisms have been proposed to explain the pleiotropic effect of a gene at the molecular level. One interesting explanation is the presence of different protein domains exerting distinct cellular functions. However, in the case of E-cadherin, this is not a valid explanation as mutations affecting the same nucleotide can induce different disorders. Instead, we propose that $\mathrm{CDH} 1$ pleiotropy is related to the specific consequences of 
each particular mutation. Indeed, we have demonstrated that specific mutations cause E-cadherin to interact differently with its binding partners, activating different signalling pathways and inducing different cell behaviours. ${ }^{9} 369697$ Notably, the same mutation can be identified in either DGC families or non-syndromic CL/P cases, suggesting that additional factors such as genetic background may have a role in the development of both diseases.

Overall, this collected knowledge changes the paradigm of E-cadherin impact that, until recently, was only focused on hereditary cancer-predisposing syndromes. From now on, birth defects and congenital anomalies, which tended to be disregarded by clinicians and many researchers, will draw more attention and will be a significant part of genetic (familial) analysis. It is expected that the development of novel tools will improve genetic testing and reveal the biological mechanisms underlying pleiotropic outcomes. These findings will have implications in management of individuals with $C D H 1$ germline alterations and will be crucial to evaluate their risk of cancer or of having a neonate affected by congenital malformations.

Acknowledgements We would like to thank the patients and families for their participation in CDH1-related studies. We also acknowledge the clinicians who sent us new mutations and information for the evaluation of variant functional impact, most of them members of the IGCLC consortium.

Contributors JF was responsible for study concept and design. JF, SM, PC, AMM, MSF and ASR have drafted the article. PG, JP and RS critically reviewed the manuscript for important intellectual content. All authors approved the final version of the manuscript.

Funding This work was financed by FEDER funds through the Operational Programme for Competitiveness Factors (COMPETE 2020), Programa Operacional de Competitividade e Internacionalização, Programa Operacional Regional do Norte (Norte 2020) and by National Funds through the Portuguese Foundation for Science and Technology, under the projects PTDC/MED-GEN/30356/2017, PTDC/ BIM-ONC/0171/2012, PTDC/BIM-ONC/0281/2014, PTDC/BBB-IMG/0283/2014, NORTE-01-0145-FEDER-000029; postdoctoral grant SFRH/BPD/87705/2012-JF and doctoral grants SFRH/BD/108009/2015-SM and SFRH/BD/114687/2016-AMM. We acknowledge the American Association of Patients with Hereditary Gastric Cancer 'No Stomach for Cancer' for funding RS and FJ's research.

\section{Competing interests None declared.}

Patient consent for publication Not required.

Provenance and peer review Not commissioned; externally peer reviewed.

Open access This is an open access article distributed in accordance with the Creative Commons Attribution Non Commercial (CC BY-NC 4.0) license, which permits others to distribute, remix, adapt, build upon this work non-commercially, and license their derivative works on different terms, provided the original work is properly cited, appropriate credit is given, any changes made indicated, and the use is non-commercial. See: http://creativecommons.org/licenses/by-nc/4.0/.

\section{REFERENCES}

1 van Roy F, Berx G. The cell-cell adhesion molecule E-cadherin. Cell Mol Life Sci 2008;65:3756-88.

2 Paredes J, Fiqueiredo J, Albergaria A, Oliveira P, Carvalho J, Ribeiro AS, Caldeira J, Costa AM, Simões-Correia J, Oliveira MJ, Pinheiro H, Pinho SS, Mateus R, Reis CA, Leite M, Fernandes MS, Schmitt F, Carneiro F, Figueiredo C, Oliveira C, Seruca R. Epithelial E- and P-cadherins: role and clinical significance in cancer. Biochim Biophys Acta 2012;1826:297-311.

3 Fleming TP, Javed Q, Hay M. Epithelial differentiation and intercellular junction formation in the mouse early embryo. Dev Supp/ 1992:105-12.

4 Larue L, Ohsugi M, Hirchenhain J, Kemler R. E-cadherin null mutant embryos fail to form a trophectoderm epithelium. Proc Natl Acad Sci U S A 1994;91:8263-7.

5 Shapiro L, Fannon AM, Kwong PD, Thompson A, Lehmann MS, Grübel G, Legrand JF, Als-Nielsen J, Colman DR, Hendrickson WA. Structural basis of cell-cell adhesion by cadherins. Nature 1995:374:327-37.

6 Aberle H, Schwartz H, Kemler R. Cadherin-catenin complex: protein interactions and their implications for cadherin function. J Cell Biochem 1996;61:514-23.

7 Okamoto R, Irie K, Yamada A, Katata T, Fukuhara A, Takai Y. Recruitment of E-cadherin associated with alpha- and beta-catenins and p120ctn to the nectinbased cell-cell adhesion sites by the action of 12-0-tetradecanoylphorbol-13-acetate in MDCK cells. Genes Cells 2005;10:435-45.
8 Kim NG, Koh E, Chen X, Gumbiner BM. E-cadherin mediates contact inhibition of proliferation through Hippo signaling-pathway components. Proc Natl Acad Sci U SA 2011;108:11930-5.

9 Mateus AR, Seruca R, Machado JC, Keller G, Oliveira MJ, Suriano G, Luber B. EGFR regulates RhoA-GTP dependent cell motility in E-cadherin mutant cells. Hum Mol Genet 2007:16:1639-47.

10 McLachlan RW, Kraemer A, Helwani FM, Kovacs EM, Yap AS. E-cadherin adhesion activates C-Src signaling at cell-cell contacts. Mol Biol Cell 2007:18:3214-23.

11 Ferreira AC, Suriano G, Mendes N, Gomes B, Wen X, Carneiro F, Seruca R, Machado $J C$. E-cadherin impairment increases cell survival through Notch-dependent upregulation of BCl-2. Hum Mol Genet 2012;21:334-43.

12 Caldeira J, Figueiredo J, Brás-Pereira C, Carneiro P, Moreira AM, Pinto MT, Relvas JB, Carneiro F, Barbosa M, Casares F, Janody F, Seruca R. E-cadherin-defective gastric cancer cells depend on Laminin to survive and invade. Hum Mol Genet 2015:24:5891-900

13 Guilford P, Hopkins J, Harraway J, McLeod M, McLeod N, Harawira P, Taite H, Scoular $\mathrm{R}$, Miller $\mathrm{A}$, Reeve AE. E-cadherin germline mutations in familial gastric cancer. Nature 1998:392:402-5.

14 Kaurah P, MacMillan A, Boyd N, Senz J, De Luca A, Chun N, Suriano G, Zaor S, Van Manen L, Gilpin C, Nikkel S, Connolly-Wilson M, Weissman S, Rubinstein WS, Sebold C, Greenstein R, Stroop J, Yim D, Panzini B, McKinnon W, Greenblatt M, Wirtzfeld D, Fontaine D, Coit D, Yoon S, Chung D, Lauwers G, Pizzuti A, Vaccaro C, Redal MA, Oliveira C, Tischkowitz M, Olschwang S, Gallinger S, Lynch H, Green J, Ford J, Pharoah P, Fernandez B, Huntsman D. Founder and recurrent CDH1 mutations in families with hereditary diffuse gastric cancer. JAMA 2007;297:2360-72.

15 Brooks-Wilson AR, Kaurah P, Suriano G, Leach S, Senz J, Grehan N, Butterfield YS, Jeyes J, Schinas J, Bacani J, Kelsey M, Ferreira P, MacGillivray B, MacLeod P, Micek M, Ford J, Foulkes W, Australie K, Greenberg C, LaPointe M, Gilpin C, Nikkel S, Gilchrist D, Hughes R, Jackson CE, Monaghan KG, Oliveira MJ, Seruca R, Gallinger S, Caldas C, Huntsman D. Germline E-cadherin mutations in hereditary diffuse gastric cancer: assessment of 42 new families and review of genetic screening criteria. J Med Genet 2004:41:508-17.

16 Hansford S, Kaurah P, Li-Chang H, Woo M, Senz J, Pinheiro H, Schrader KA, Schaeffer DF, Shumansky K, Zogopoulos G, Santos TA, Claro I, Carvalho J, Nielsen C, Padilla S, Lum A, Talhouk A, Baker-Lange K, Richardson S, Lewis I, Lindor NM, Pennell E, MacMillan A, Fernandez B, Keller G, Lynch H, Shah SP, Guilford P, Gallinger S, Corso G, Roviello F, Caldas C, Oliveira C, Pharoah PD, Huntsman DG. Hereditary diffuse gastric cancer syndrome: cdh1 mutations and beyond. JAMA Oncol 2015;1:23-32.

17 Kluiit I, Siemerink EJ, Ausems MG, van Os TA, de Jong D, Simões-Correia J, van Krieken JH, Ligtenberg MJ, Figueiredo J, van Riel E, Sijmons RH, Plukker JT, van Hillegersberg R, Dekker E, Oliveira C, Cats A, Hoogerbrugge N. Dutch Working Group on Hereditary Gastric Cancer. CDH1-related hereditary diffuse gastric cancer syndrome: clinical variations and implications for counseling. Int I Cancer 2012:131:367-76.

18 Keller G, Vogelsang H, Becker I, Hutter J, Ott K, Candidus S, Grundei T, Becker KF, Mueller J, Siewert JR, Höfler H. Diffuse type gastric and lobular breast carcinoma in a familial gastric cancer patient with an E-cadherin germline mutation. Am J Pathol 1999:155:337-42.

19 Benusiglio PR, Malka D, Rouleau E, De Pauw A, Buecher B, Noguès C, Fourme E, Colas C, Coulet F, Warcoin M, Grandjouan S, Sezeur A, Laurent-Puig P, Molière D, Tlemsani C, Di Maria M, Byrde V, Delaloge S, Blayau M, Caron 0. CDH1 germline mutations and the hereditary diffuse gastric and lobular breast cancer syndrome: a multicentre study. J Med Genet 2013;50:486-9.

20 Frebourg T, Oliveira C, Hochain P, Karam R, Manouvrier S, Graziadio C, Vekemans M, Hartmann A, Baert-Desurmont S, Alexandre C, Lejeune Dumoulin S, Marroni C, Martin C, Castedo S, Lovett M, Winston J, Machado JC, Attié T, Jabs EW, Cai J, Pellerin P, Triboulet JP, Scotte M, Le Pessot F, Hedouin A, Carneiro F, Blayau M, Seruca R. Cleft lip/palate and CDH1/E-cadherin mutations in families with hereditary diffuse gastric cancer. J Med Genet 2006:43:138-42.

21 van der Post RS, Vogelaar IP, Carneiro F, Guilford P, Huntsman D, Hoogerbrugge $\mathrm{N}$, Caldas C, Schreiber KE, Hardwick RH, Ausems MG, Bardram L, Benusiglio PR, Bisseling TM, Blair V, Bleiker E, Boussioutas A, Cats A, Coit D, DeGregorio L, Figueiredo J, Ford JM, Heijkoop E, Hermens R, Humar B, Kaurah P, Keller G, Lai J, Ligtenberg MJ, O'Donovan M, Oliveira C, Pinheiro H, Ragunath K, Rasenberg E, Richardson S, Roviello F, Schackert H, Seruca R, Taylor A, Ter Huurne A, Tischkowitz M, Joe ST, van Dijck B, van Grieken NC, van Hillegersberg R, van Sandick JW, Vehof $R$, van Krieken JH, Fitzgerald RC. Hereditary diffuse gastric cancer: updated clinical guidelines with an emphasis on germline $\mathrm{CDH} 1$ mutation carriers. J Med Genet 2015;52:361-74

22 Vogelaar IP, Fiqueiredo J, van Rooij IA, Simões-Correia J, van der Post RS, Melo S, Seruca R, Carels CE, Ligtenberg MJ, Hoogerbrugge N. Identification of germline mutations in the cancer predisposing gene CDH1 in patients with orofacial clefts. Hum Mol Genet 2013;22:919-26.

23 Xie ZM, Li LS, Laquet C, Penault-Llorca F, Uhrhammer N, Xie XM, Bignon YJ. Germline mutations of the $\mathrm{E}$-cadherin gene in families with inherited invasive lobular breast carcinoma but no diffuse gastric cancer. Cancer 2011;117:3112-7.

24 Brito LA, Yamamoto GL, Melo S, Malcher C, Ferreira SG, Figueiredo J, Alvizi L, Kobayashi GS, Naslavsky MS, Alonso N, Felix TM, Zatz M, Seruca R, Passos-Bueno 
MR. Rare variants in the epithelial cadherin gene underlying the genetic etiology of nonsyndromic cleft lip with or without cleft palate. Hum Mutat 2015;36:1029-33.

25 Corso G, Figueiredo J, La Vecchia C, Veronesi P, Pravettoni G, Macis D, Karam R, Lo Gullo R, Provenzano E, Toesca A, Mazzocco K, Carneiro F, Seruca R, Melo S, Schmitt F, Roviello F, De Scalzi AM, Intra M, Feroce I, De Camilli E, Villardita MG, Trentin C, De Lorenzi F, Bonanni B, Galimberti V. Hereditary lobular breast cancer with an emphasis on E-cadherin genetic defect. J Med Genet 2018;55:431-41.

26 Guilford PJ, Hopkins JB, Grady WM, Markowitz SD, Willis J, Lynch H, Rajput A, Wiesner GL, Lindor NM, Burgart LJ, Toro TT, Lee D, Limacher JM, Shaw DW, Findlay MP, Reeve AE. E-cadherin germline mutations define an inherited cancer syndrome dominated by diffuse gastric cancer. Hum Mutat 1999;14:249-55.

27 More H, Humar B, Weber W, Ward R, Christian A, Lintott C, Graziano F, Ruzzo AM, Acosta E, Boman B, Harlan M, Ferreira P, Seruca R, Suriano G, Guilford P. Identification of seven novel germline mutations in the human E-cadherin (CDH1) gene. Hum Mutat 2007;28:203.

28 Suriano G, Oliveira C, Ferreira P, Machado JC, Bordin MC, De Wever O, Bruyneel EA, Moguilevsky N, Grehan N, Porter TR, Richards FM, Hruban RH, Roviello F, Huntsman D, Mareel M, Carneiro F, Caldas C, Seruca R. Identification of CDH1 germline missense mutations associated with functional inactivation of the $\mathrm{E}$-cadherin protein in young gastric cancer probands. Hum Mol Genet 2003;12:575-82.

29 Oliveira C, Pinheiro H, Figueiredo J, Seruca R, Carneiro F. Familial gastric cancer: genetic susceptibility, pathology, and implications for management. Lancet Oncol 2015;16:e60-e70.

30 Pharoah PD, Guilford P, Caldas C. Incidence of gastric cancer and breast cancer in CDH1 (E-cadherin) mutation carriers from hereditary diffuse gastric cancer families. Gastroenterology 2001;121:1348-53.

31 Richards FM, McKee SA, Rajpar MH, Cole TR, Evans DG, Jankowski JA, McKeown C, Sanders DS, Maher ER. Germline E-cadherin gene ( $\mathrm{CDH1}$ ) mutations predispose to familial gastric cancer and colorectal cancer. Hum Mol Genet 1999;8:607-10.

32 Hamilton LE, Jones K, Church N, Medlicott S. Synchronous appendiceal and intramucosal gastric signet ring cell carcinomas in an individual with CDH1associated hereditary diffuse gastric carcinoma: a case report of a novel association and review of the literature. BMC Gastroenterol 2013;13:114.

33 Oliveira C, Bordin MC, Grehan N, Huntsman D, Suriano G, Machado JC, Kiviluoto T, Aaltonen $\mathrm{L}$, Jackson $\mathrm{CE}$, Seruca $\mathrm{R}$, Caldas C. Screening E-cadherin in gastric cancer families reveals germline mutations only in hereditary diffuse gastric cancer kindred. Hum Mutat 2002;19:510-7.

34 Oliveira C, Pinheiro H, Figueiredo J, Seruca R, Carneiro F. E-cadherin alterations in hereditary disorders with emphasis on hereditary diffuse gastric cancer. Prog Mol Biol Trans/ Sci 2013;116:337-59.

35 Melo S, Figueiredo J, Fernandes MS, Gonçalves M, Morais-de-Sá E, Sanches JM, Seruca R. Predicting the functional impact of $c \mathrm{dh} 1$ missense mutations in hereditary diffuse gastric cancer. Int J Mo/ Sci 2017;18:2687

36 Figueiredo J, Söderberg O, Simões-Correia J, Grannas K, Suriano G, Seruca R. The importance of $\mathrm{E}$-cadherin binding partners to evaluate the pathogenicity of E-cadherin missense mutations associated to HDGC. Eur J Hum Genet 2013;21:301-9.

37 Corso G, Fiqueiredo J, Biffi R, Trentin C, Bonanni B, Feroce I, Serrano D, Cassano E, Annibale B, Melo S, Seruca R, De Lorenzi F, Ferrara F, Piagnerelli R, Roviello F, Galimberti V. E-cadherin germline mutation carriers: clinical management and genetic implications. Cancer Metastasis Rev 2014;33:1081-94.

38 Oliveira C, Sousa S, Pinheiro H, Karam R, Bordeira-Carriço R, Senz J, Kaurah P, Carvalho J, Pereira R, Gusmão L, Wen X, Cipriano MA, Yokota J, Carneiro F Huntsman D, Seruca R. Quantification of epigenetic and genetic 2nd hits in $\mathrm{CDH} 1$ during hereditary diffuse gastric cancer syndrome progression. Gastroenterology 2009;136:2137-48

39 Grady WM, Willis J, Guilford PJ, Dunbier AK, Toro TT, Lynch H, Wiesner G, Ferguson K, Eng C, Park JG, Kim SJ, Markowitz S. Methylation of the CDH1 promoter as the second genetic hit in hereditary diffuse gastric cancer. Nat Genet 2000;26:16-17.

40 Oliveira C, de Bruin J, Nabais S, Ligtenberg M, Moutinho C, Nagengast FM, Seruca R, van Krieken $\mathrm{H}$, Carneiro F. Intragenic deletion of $\mathrm{CDH} 1$ as the inactivating mechanism of the wild-type allele in an HDGC tumour. Oncogene 2004; $23: 2236-40$

41 Barber M, Murrell A, Ito Y, Maia AT, Hyland S, Oliveira C, Save V, Carneiro F, Paterson AL, Grehan N, Dwerryhouse S, Lao-Sirieix P, Caldas C, Fitzgerald RC. Mechanisms and sequelae of E-cadherin silencing in hereditary diffuse gastric cancer. J Pathol 2008;216:295-306

42 Carneiro F, Huntsman DG, Smyrk TC, Owen DA, Seruca R, Pharoah P, Caldas C, Sobrinho-Simões M. Model of the early development of diffuse gastric cancer in E-cadherin mutation carriers and its implications for patient screening. J Pathol 2004; 203:681-7.

43 van der Post RS, Carneiro F. Emerging concepts in gastric neoplasia: heritable gastric cancers and polyposis disorders. Surg Pathol Clin 2017;10:931-45.

44 Oliveira C, Seruca R, Carneiro F. Genetics, pathology, and clinics of familial gastric cancer. Int J Surg Pathol 2006;14:21-33.

45 Caldas C, Carneiro F, Lynch HT, Yokota J, Wiesner GL, Powell SM, Lewis FR, Huntsman DG, Pharoah PD, Jankowski JA, MacLeod P, Vogelsang H, Keller G, Park KG, Richards FM, Maher ER, Gayther SA, Oliveira C, Grehan N, Wight D, Seruca R, Roviello
F, Ponder BA, Jackson CE. Familial gastric cancer: overview and guidelines for management. J Med Genet 1999;36:873-80.

46 Fitzgerald RC, Caldas C. Clinical implications of E-cadherin associated hereditary diffuse gastric cancer. Gut 2004:53:775-8.

47 Fitzgerald RC, Hardwick R, Huntsman D, Carneiro F, Guilford P, Blair V, Chung DC, Norton J, Ragunath K, Van Krieken JH, Dwerryhouse S, Caldas C. International Gastric Cancer Linkage Consortium. Hereditary diffuse gastric cancer: updated consensus guidelines for clinical management and directions for future research. J Med Genet 2010;47:436-44.

48 Huntsman DG, Carneiro F, Lewis FR, MacLeod PM, Hayashi A, Monaghan KG, Maung $R$, Seruca $R$, Jackson $C E$, Caldas $C$. Early gastric cancer in young, asymptomatic carriers of germ-line E-cadherin mutations. N Eng/ J Med 2001;344:1904-9.

49 Lynch HT, Kaurah P, Wirtzfeld D, Rubinstein WS, Weissman S, Lynch JF, Grady W, Wiyrick S, Senz J, Huntsman DG. Hereditary diffuse gastric cancer: diagnosis, genetic counseling, and prophylactic total gastrectomy. Cancer 2008;112:2655-63.

50 van der Post RS, Vogelaar IP, Manders P, van der Kolk LE, Cats A, van Hest LP, Sijmons R, Aalfs CM, Ausems MGEM, Gómez García EB, Wagner A, Hes FJ, Arts N, Mensenkamp AR, van Krieken JH, Hoogerbrugge N, Ligtenberg MJL. Accuracy of hereditary diffuse gastric cancer testing criteria and outcomes in patients with a germline mutation in CDH1. Gastroenterology 2015;149:e19:897-906.

51 Barber ME, Save V, Carneiro F, Dwerryhouse S, Lao-Sirieix P, Hardwick RH, Caldas C, Fitzgerald RC. Histopathological and molecular analysis of gastrectomy specimens from hereditary diffuse gastric cancer patients has implications for endoscopic surveillance of individuals at risk. J Pathol 2008;216:286-94.

52 Majewski IJ, Kluijt I, Cats A, Scerri TS, de Jong D, Kluin RJ, Hansford S, Hogervorst FB, Bosma AJ, Hofland I, Winter M, Huntsman D, Jonkers J, Bahlo M, Bernards R. An $\alpha$-E-catenin (CTNNA1) mutation in hereditary diffuse gastric cancer. J Pathol 2013:229:621-9.

53 Weren RDA, van der Post RS, Vogelaar IP, van Krieken JH, Spruijt L, Lubinski J, Jakubowska A, Teodorczyk U, Aalfs CM, van Hest LP, Oliveira C, Kamping EJ, Schackert HK, Ranzani GN, Gómez García EB, Hes FJ, Holinski-Feder E, Genuardi M, Ausems M, Sijmons RH, Wagner A, van der Kolk LE, Cats A, Bjørnevoll I, Hoogerbrugge N, Ligtenberg MJL. Role of germline aberrations affecting CTNNA1, MAP3K6 and MYD88 in gastric cancer susceptibility. J Med Genet 2018;55:669-74.

54 Donner I, Kiviluoto T, Ristimäki A, Aaltonen LA, Vahteristo P. Exome sequencing reveals three novel candidate predisposition genes for diffuse gastric cancer. Fam Cancer 2015;14:241-6.

55 Gaston D, Hansford S, Oliveira C, Nightingale M, Pinheiro H, Macgillivray C, Kaurah P, Rideout AL, Steele P, Soares G, Huang WY, Whitehouse S, Blowers S, LeBlanc MA Jiang $H$, Greer W, Samuels ME, Orr A, Fernandez CV, Majewski J, Ludman M, Dyack S, Penney LS, McMaster CR, Huntsman D, Bedard K. Germline mutations in MAP3K6 are associated with familial gastric cancer. PLoS Genet 2014;10:e1004669.

56 Vogelaar IP, van der Post RS, van Krieken JHJ, Spruijt L, van Zelst-Stams WA, Kets CM Lubinski J, Jakubowska A, Teodorczyk U, Aalfs CM, van Hest LP, Pinheiro H, Oliveira C, Jhangiani SN, Muzny DM, Gibbs RA, Lupski JR, de Ligt J, Vissers L, Hoischen A, Gilissen C, van de Vorst M, Goeman JJ, Schackert HK, Ranzani GN, Molinaro V Gómez García EB, Hes FJ, Holinski-Feder E, Genuardi M, Ausems M, Sijmons RH, Wagner A, van der Kolk LE, Bjørnevoll I, Høberg-Vetti H, van Kessel AG, Kuiper RP, Ligtenberg MJL, Hoogerbrugge N. Unraveling genetic predisposition to familial or early onset gastric cancer using germline whole-exome sequencing. Eur J Hum Genet 2017;25:1246-52.

57 Masciari S, Larsson N, Senz J, Boyd N, Kaurah P, Kandel MJ, Harris LN, Pinheiro HC, Troussard A, Miron P, Tung N, Oliveira C, Collins L, Schnitt S, Garber JE, Huntsman D. Germline E-cadherin mutations in familial lobular breast cancer. J Med Genet 2007:44:726-31.

58 Corso G, Intra M, Trentin C, Veronesi P, Galimberti V. CDH1 germline mutations and hereditary lobular breast cancer. Fam Cancer 2016;15:215-9.

59 Schrader KA, Masciari S, Boyd N, Salamanca C, Senz J, Saunders DN, Yorida E, Maines-Bandiera S, Kaurah P, Tung N, Robson ME, Ryan PD, Olopade OI, Domchek SM, Ford J, Isaacs C, Brown P, Balmana J, Razzak AR, Miron P, Coffey K, Terry MB, John EM, Andrulis IL, Knight JA, O'Malley FP, Daly M, Bender P, Moore R, Southey MC, Hopper JL, Garber JE, Huntsman DG. KConFab. Germline mutations in CDH1 are infrequent in women with early-onset or familial lobular breast cancers. J Med Genet 2011:48:64-8.

60 Petridis C, Shinomiya I, Kohut K, Gorman P, Caneppele M, Shah V, Troy M, Pinder SE, Hanby A, Tomlinson I, Trembath RC, Roylance R, Simpson MA, Sawyer EJ. Germline CDH1 mutations in bilateral lobular carcinoma in situ. Br J Cancer 2014;110:1053-7.

61 Dossus L, Benusiglio PR. Lobular breast cancer: incidence and genetic and nongenetic risk factors. Breast Cancer Res 2015:17:37.

62 Wittersheim M, Büttner R, Markiefka B. Genotype/Phenotype correlations in patients with hereditary breast cancer. Breast Care 2015;10:22-6.

63 Ciriello G, Gatza ML, Beck AH, Wilkerson MD, Rhie SK, Pastore A, Zhang H, McLellan M, Yau C, Kandoth C, Bowlby R, Shen H, Hayat S, Fieldhouse R, Lester SC, Tse GM, Factor RE, Collins LC, Allison KH, Chen YY, Jensen K, Johnson NB, Oesterreich $S$, Mills GB, Cherniack AD, Robertson G, Benz C, Sander C, Laird PW, Hoadley KA, King TA, Perou CM. TCGA Research Network. Comprehensive molecular portraits of invasive lobular breast cancer. Cell 2015;163:506-19. 
64 Rakha EA, Patel A, Powe DG, Benhasouna A, Green AR, Lambros MB, Reis-Filho JS, Ellis IO. Clinical and biological significance of E-cadherin protein expression in invasive lobular carcinoma of the breast. Am J Surg Pathol 2010;34:1472-9.

65 Rakha EA, Teoh TK, Lee AH, Nolan CC, Ellis IO, Green AR. Further evidence that $\mathrm{E}$-cadherin is not a tumour suppressor gene in invasive ductal carcinoma of the breast: an immunohistochemical study. Histopathology 2013;62:695-701.

66 Tavassoli FA, Devilee P. World Health Organization Classification of Tumours. Pathology and Genetics of Tumours of the Breast and Female Genital Organs. Lyon: IARC Press, 2003.

67 Hanby AM, Hughes TA. In situ and invasive lobular neoplasia of the breast. Histopathology 2008;52:58-66.

68 Stuebs F, Heidemann S, Caliebe A, Mundhenke C, Arnold N. CDH1 mutation screen in a BRCA1/2-negative familial breast-/ovarian cancer cohort. Arch Gynecol Obstet 2018;297:147-52.

69 Keller G, Vogelsang H, Becker I, Plaschke S, Ott K, Suriano G, Mateus AR, Seruca R, Biedermann K, Huntsman D, Döring C, Holinski-Feder E, Neutzling A, Siewert JR, Höfler $\mathrm{H}$. Germline mutations of the E-cadherin(CDH1) and TP53 genes, rather than of RUNX3 and HPP1, contribute to genetic predisposition in German gastric cancer patients. J Med Genet 2004;41:e89.

70 Yabuta T, Shinmura K, Tani M, Yamaguchi S, Yoshimura K, Katai H, Nakajima T, Mochiki E, Tsujinaka T, Takami M, Hirose K, Yamaguchi A, Takenoshita S, Yokota J. $\mathrm{E}$-cadherin gene variants in gastric cancer families whose probands are diagnosed with diffuse gastric cancer. Int J Cancer 2002;101:434-41.

71 Kim HC, Wheeler JM, Kim JC, Ilyas M, Beck NE, Kim BS, Park KC, Bodmer WF. The E-cadherin gene (CDH1) variants T340A and L599V in gastric and colorectal cancer patients in Korea. Gut 2000;47:262-7.

72 Salahshor S, Hou H, Diep CB, Loukola A, Zhang H, Liu T, Chen J, Iselius L, Rubio C, Lothe RA, Aaltonen L, Sun XF, Lindmark G, Lindblom A. A germline E-cadherin mutation in a family with gastric and colon cancer. Int J Mol Med 2001;8:439-43.

73 Houlston RS, Webb E, Broderick P, Pittman AM, Di Bernardo MC, Lubbe S, Chandler I, Vijayakrishnan J, Sullivan K, Penegar S, Carvajal-Carmona L, Howarth K, Jaeger E, Spain SL, Walther A, Barclay E, Martin L, Gorman M, Domingo E, Teixeira AS, Kerr D, Cazier JB, Niittymäki I, Tuupanen S, Karhu A, Aaltonen LA, Tomlinson IP, Farrington SM, Tenesa A, Prendergast JG, Barnetson RA, Cetnarskyj R, Porteous ME, Pharoah PD, Koessler T, Hampe J, Buch S, Schafmayer C, Tepel J, Schreiber S, Völzke H, Chang-Claude J, Hoffmeister M, Brenner H, Zanke BW, Montpetit A, Hudson TJ, Gallinger S, Campbell H, Dunlop MG. COGENT Study Colorectal Cancer Association Study Consortium CoRGI Consortium. Meta-analysis of genome-wide association data identifies four new susceptibility loci for colorectal cancer. Nat Genet 2008;40:1426-35

74 Kraus C, Rau TT, Lux P, Erlenbach-Wünsch K, Löhr S, Krumbiegel M, Thiel CT, Stöhr R, Agaimy A, Croner RS, Stürzl M, Hohenberger W, Hartmann A, Reis A. Comprehensive screening for mutations associated with colorectal cancer in unselected cases reveals penetrant and nonpenetrant mutations. Int J Cancer 2015;136:E559-E568.

75 Pittman AM, Twiss P, Broderick P, Lubbe S, Chandler I, Penegar S, Houlston RS. The CDH1-160C $>$ A polymorphism is a risk factor for colorectal cancer. Int J Cancer 2009;125:1622-5.

76 Barrett JC, Lee JC, Lees CW, Prescott NJ, Anderson CA, Phillips A, Wesley E, Parnell K, Zhang H, Drummond H, Nimmo ER, Massey D, Blaszczyk K, Elliott T, Cotterill L, Dallal H, Lobo AJ, Mowat C, Sanderson JD, Jewell DP, Newman WG, Edwards C, Ahmad T, Mansfield JC, Satsangi J, Parkes M, Mathew CG, Donnelly P, Peltonen L, Blackwell JM, Bramon E, Brown MA, Casas JP, Corvin A, Craddock N, Deloukas P, Duncanson A, Jankowski J, Markus HS, Mathew CG, McCarthy MI, Palmer CN, Plomin R, Rautanen A, Sawcer SJ, Samani N, Trembath RC, Viswanathan AC, Wood N, Spencer CC, Barrett JC, Bellenguez C, Davison D, Freeman C, Strange A, Donnelly P, Langford C, Hunt SE, Edkins S, Gwilliam R, Blackburn H, Bumpstead SJ, Dronov S, Gillman M, Gray E, Hammond N, Jayakumar A, McCann OT, Liddle J, Perez ML, Potter SC, Ravindrarajah R, Ricketts M, Waller M, Weston P, Widaa S, Whittaker P, Deloukas P, Peltonen L, Mathew CG, Blackwell JM, Brown MA, Corvin A, McCarthy MI, Spencer CC, Attwood AP, Stephens J, Sambrook J, Ouwehand WH, McArdle WL, Ring SM, Strachan DP. UK IBD Genetics Consortium Wellcome Trust Case Control Consortium 2. Genome-wide association study of ulcerative colitis identifies three new susceptibility loci, including the HNF4A region. Nat Genet 2009;41:1330-4.

77 Mossey PA, Little J, Munger RG, Dixon MJ, Shaw WC. Cleft lip and palate. Lancet 2009;374:1773-85.

78 Dixon MJ, Marazita ML, Beaty TH, Murray JC. Cleft lip and palate: understanding genetic and environmental influences. Nat Rev Genet 2011;12:167-78.

79 Bureau A, Parker MM, Ruczinski I, Taub MA, Marazita ML, Murray JC, Mangold E, Noethen MM, Ludwig KU, Hetmanski JB, Bailey-Wilson JE, Cropp CD, Li Q, Szymczak S, Albacha-Hejazi H, Alqosayer K, Field LL, Wu-Chou YH, Doheny KF, Ling $\mathrm{H}$, Scott AF, Beaty TH. Whole exome sequencing of distant relatives in multiplex families implicates rare variants in candidate genes for oral clefts. Genetics 2014;197:1039-44.
80 Alvizi L, Ke X, Brito LA, Seselgyte R, Moore GE, Stanier P, Passos-Bueno MR. Differential methylation is associated with non-syndromic cleft lip and palate and contributes to penetrance effects. Sci Rep 2017;7:2441

81 Cox LL, Cox TC, Moreno Uribe LM, Zhu Y, Richter CT, Nidey N, Standley JM, Deng M, Blue E, Chong JX, Yang Y, Carstens RP, Anand D, Lachke SA, Smith JD, Dorschner MO Bedell B, Kirk E, Hing AV, Venselaar H, Valencia-Ramirez LC, Bamshad MJ, Glass IA, Cooper JA, Haan E, Nickerson DA, van Bokhoven H, Zhou H, Krahn KN, Buckley MF, Murray JC, Lidral AC, Roscioli T. Mutations in the epithelial cadherin-p120-catenin complex cause mendelian non-syndromic cleft lip with or without cleft palate. Am J Hum Genet 2018;102:1143-57.

82 Letra A, Menezes R, Granjeiro JM, Vieira AR. AXIN2 and CDH1 polymorphisms, tooth agenesis, and oral clefts. Birth Defects Res A Clin Mol Teratol 2009;85:169-73.

83 Song Y, Zhang S. Association of CDH1 promoter polymorphism and the risk of non-syndromic orofacial clefts in a Chinese Han population. Arch Oral Biol 2011;:56:68-72.

84 Nishi E, Masuda K, Arakawa M, Kawame H, Kosho T, Kitahara M, Kubota N, Hidaka E, Katoh Y, Shirahige K, Izumi K. Exome sequencing-based identification of mutations in non-syndromic genes among individuals with apparently syndromic features. $\mathrm{Am} \mathrm{J}$ Med Genet A 2016:170:2889-94.

85 Ghoumid J, Stichelbout M, Jourdain AS, Frenois F, Lejeune-Dumoulin S, AlexCordier MP, Lebrun M, Guerreschi P, Duquennoy-Martinot V, Vinchon M, Ferri J, Jung M, Vicaire S, Vanlerberghe C, Escande F, Petit F, Manouvrier-Hanu S. Blepharocheilodontic syndrome is a $\mathrm{CDH} 1$ pathway-related disorder due to mutations in CDH1 and CTNND1. Genet Med 2017;19:1013-21.

86 Kievit A, Tessadori F, Douben H, Jordens I, Maurice M, Hoogeboom J, Hennekam R, Nampoothiri S, Kayserili H, Castori M, Whiteford M, Motter C, Melver C, Cunningham M, Hing A, Kokitsu-Nakata NM, Vendramini-Pittoli S, Richieri-Costa A, Baas AF, Breugem CC, Duran K, Massink M, Derksen PWB, van IJcken WFJ, van Unen L, Santos-Simarro F, Lapunzina P, Gil-da Silva Lopes VL, Lustosa-Mendes E, Krall M, Slavotinek A, Martinez-Glez V, Bakkers J, van Gassen KLI, de Klein A, van den Boogaard MH, van Haaften G. Variants in members of the cadherin-catenin complex, CDH1 and CTNND1, cause blepharocheilodontic syndrome. Eur J Hum Genet 2018:26:210-9

87 Elschnig A. Zur kenntnis der anomalien der lidspaltenform. Klin Monatsb/ Augenheilkd 1912;50:17-30.

88 Gorlin RJ, Zellweger H, Curtis MW, Wiedemann HR, Warburg M, Majewski F, Gillessen-Kaesbach G, Prahl-Andersen B, Zackai E. Blepharo-cheilo-dontic (BCD) syndrome. Am J Med Genet 1996;65:109-12.

89 Allanson JE, McGillivray BC. Familial clefting syndrome with ectropion and dental anomaly--without limb anomalies. Clin Genet 1985;27:426-9.

90 Freitas EL, Martinhago CD, Ramos ES, Murray JC, Gil-da-Silva-Lopes VL. Preliminary molecular studies on blepharocheilodontic syndrome. Am J Med Genet $A$ 2007;143A:2757-9.

91 Gil da Silva Lopes VL, Guion-Almeida ML, de Oliveira Rodini ES. Blepharocheilodontic (BCD) syndrome: expanding the phenotype? Am J Med Genet A 2003;121A:266-70.

92 Guion-Almeida ML, Rodini ES, Kokitsu-Nakata NM, Bologna-Amantini D. BlepharoCheilo-Dontic (BCD) syndrome: report on four new patients. Am J Med Genet 1998:76:133-6

93 Ishiyama N, Lee SH, Liu S, Li GY, Smith MJ, Reichardt LF, Ikura M. Dynamic and static interactions between p120 catenin and E-cadherin regulate the stability of cell-cell adhesion. Cell 2010;141:117-28

94 Davis MA, Ireton RC, Reynolds AB. A core function for p120-catenin in cadherin turnover. J Cell Biol 2003;163:525-34.

95 Sivakumaran S, Agakov F, Theodoratou E, Prendergast JG, Zgaga L, Manolio T, Rudan I, McKeigue P, Wilson JF, Campbell H. Abundant pleiotropy in human complex diseases and traits. Am J Hum Genet 2011;89:607-18.

96 Simões-Correia J, Silva DI, Melo S, Figueiredo J, Caldeira J, Pinto MT, Girão H, Pereira P, Seruca R. DNAJB4 molecular chaperone distinguishes WT from mutant E-cadherin, determining their fate in vitro and in vivo. Hum Mol Genet 2014;23:2094-105.

97 Pereira PS, Teixeira A, Pinho S, Ferreira P, Fernandes J, Oliveira C, Seruca R, Suriano $\mathrm{G}$, Casares F. E-cadherin missense mutations, associated with hereditary diffuse gastric cancer (HDGC) syndrome, display distinct invasive behaviors and genetic interactions with the Wnt and Notch pathways in Drosophila epithelia. Hum Mol Genet 2006;15:1704-12.

98 Molinaro V, Pensotti V, Marabelli M, Feroce I, Barile M, Pozzi S, Laghi L, Serrano D, Bernard L, Bonanni B, Ranzani GN. Complementary molecular approaches reveal heterogeneous $\mathrm{CDH} 1$ germline defects in Italian patients with hereditary diffuse gastric cancer (HDGC) syndrome. Genes Chromosomes Cancer 2014;53:432-45.

99 Benusiglio PR, Caron O, Consolino E, Duvillard P, Coulet F, Blayau M, Malka D. Cleft lip, cleft palate, hereditary diffuse gastric cancer and germline mutations in $\mathrm{CDH} 1$. Int J Cancer 2013;132:2470.

100 Guilford P, Humar B, Blair V. Hereditary diffuse gastric cancer: translation of CDH1 germline mutations into clinical practice. Gastric Cancer 2010;13:1-10. 